\title{
EFFECTS OF POTASSIUM ON RENAL TUBULAR REABSORPTION OF BICARBONATE ${ }^{1,2}$
}

\author{
BY KATHLEEN E. ROBERTS, HENRY T. RANDALL, HAROLD L. SANDERS, AND \\ MARGARET HOOD WITH THE TECHNICAL ASSISTANCE OF SERGEI DENECKO, \\ RITA LIPTON, AND FRANKIE LAWSON \\ (From The Division of Experimental Surgery, Andre and Bella Meyer Physiology Laboratories \\ of The Sloan-Kettering Institute, and The Departments of Surgery and Medicine, \\ Memorial Center, New York, N. Y.)
}

(Submitted for publication September 1, 1954; accepted December 22, 1954)

It is generally recognized that potassium deprivation may result in the development of a plasma alkalosis, which is characterized by the paradoxical excretion of an acid urine (1-12). Conversely, the administration of sufficient potassium chloride results in a plasma acidosis and the simultaneous excretion of an alkaline urine $(8,13-16)$. Studies previously reported have shown that the dichotomous plasma and urinary findings following potassium administration result from a decrease in the renal tubular reabsorption of base-bound bicarbonate (13). The inappropriate aciduria occurring in hypokalemic alkalosis has led to the suggestion that renal reabsorption of bicarbonate is increased in circumstances where inadequate intake or excessive losses of potassium have occurred $(1,13,17)$. This implies a renal failure to compensate the plasma alkalosis accompanying hypokalemia and assumes a renal contribution to the continuation of the plasma alkalosis. Although it has not been measured previously, it would appear virtually certain that hypokalemia enhances the renal tubular reabsorption of bicarbonate; the mechanism whereby the influence of potassium is mediated, however, remains more speculative (1, 13, 17). Accordingly, the studies described herein were carried out on human subjects and on dogs 1) to determine the effects of potassium depletion on the renal mechanisms implicated in stabilizing the plasma bicarbonate, and 2) to clarify the mechanisms whereby potassium influences the renal tubular reabsorption and urinary excretion of bicarbonate bound base.

The studies reported below indicate that hypokalemia results in an increased renal tubular reab-

1 This work was presented, in part, at the meetings of the American Society for Clinical Investigation in Atlantic City, May, 1954.

2 This work was supported by United States Public Health Service Grant H-1641. sorption of bicarbonate, and that the effects of potassium are independent of alterations in plasma $\mathrm{pCO}_{2}$.

\section{METHODS}

The following experiments were carried out on 10 human subjects and on 6 dogs. Six of the patients had gastric cancer and were studied on a metabolic balance regimen: a) During a control period; and b) during an interval of potassium deprivation. The studies completed on these patients included measurements of glomerular filtration rate and urinary bicarbonate, sodium, potassium, chloride, and $\mathrm{pH}$. Plasma was analyzed daily for $\mathrm{pH}$, carbon dioxide content, chloride, sodium and potassium. Metabolic studies included daily measurements and analyses of intake and fecal drainage, and urinary losses of chloride, potassium and sodium. During the control period, the renal tubular reabsorption of bicarbonate was determined previous to and following the infusion of 1000 to $1500 \mathrm{cc}$. of M/6 lactate or 2 per cent sodium bicarbonate to ensure frank excretion of bicarbonate and an alkaline urine. The patients were then maintained, following gastrectomy, on potassium-free, parenteral fluids for an interval of 5 to 19 days. Daily fluid replacement given the patients included glucose in water, normal saline, and B vitamins. No postoperative complications occurred in the patients during the interval of study reported here. At the termination of the hypokalemic period, the renal tubular excretion and reabsorption of bicarbonate was again measured and compared to that observed in the control period. ${ }^{3}$ Four additional patients were studied during an episode of hypokalemic alkalosis. In these patients, measurement of the renal excretion and reabsorption of bicarbonate was made during the period of alkalosis; no metabolic studies were done in these patients.* (In two of these patients renal clearances were measured during a period of adequate potassium supplementa-

${ }^{8}$ Metabolic balances showed a negative potassium balance in these patients ranging between 180 and $280 \mathrm{mEq}$.; no attempt was made in these studies to correlate the degree of potassium depletion with bicarbonate reabsorption.

4 One of these patients had hyperadrenocorticism. Two patients were receiving cortisone with inadequate potassium supplementation and one patient had potassium depletion resulting from an inadequate dietary intake and diarrhea secondary to a severe dumping syndrome. 
tion and at a time when plasma electrolytes were normal.)

The experiments carried out on dogs were designed to determine the effects of potassium on the enhanced bicarbonate reabsorption, which has been reported to occur following elevations in plasma $\mathrm{pCO}_{2}(17-19)$. In these experiments, sodium bicarbonate was infused throughout to ensure adequate urinary excretion of bicarbonate; the animals were then given 10 per cent $\mathrm{CO}_{2}$ to breathe for periods of two to six hours, and the renal tubular reabsorption of bicarbonate determined before and after the infusion of potassium chloride, given at rates of 0.3 to $0.5 \mathrm{mEq}$. per minute for 120 to 360 minutes.

The clearance of inulin was utilized as a measure of glomerular filtration rate in the human subjects and in the dogs. The methods employed in the chemical analysis and collection of samples have been described in previous communications $(13,20)$. Urine was collected under oil from an indwelling catheter for $\mathrm{pH}$ and carbon dioxide analyses, which were done within two to five hours after - collection. The remaining urine was preserved for subsequent analysis. Plasma analyses of total $\mathrm{CO}_{2}$ and $\mathrm{pH}$ in the patients were determined on venous blood drawn without stasis; in the dogs the plasma analyses were determined from arterial blood. The reabsorption of bicarbonate was calculated as that amount reabsorbed per $100 \mathrm{cc}$. of glomerular filtrate by subtracting the excreted moiety from that filtered.

\section{RESULTS}

Table I shows the renal tubular reabsorption and excretion of bicarbonate in one of the patients

\section{TABLE I}

Reabsorption of bicarbonate bound base in the control period previous to and during the infusion of sufficient $M / 6$ lactate to elevate the plasma bicarbonate to levels shown here and in the same patient following an interval of potassium free fluids for six days

\begin{tabular}{|c|c|c|c|c|c|}
\hline \multirow[b]{3}{*}{$\begin{array}{l}\text { Time } \\
\min .\end{array}$} & \multirow[b]{3}{*}{$\begin{array}{l}\text { Plasma } \\
\text { bicarbonate } \\
m E q . / L\end{array}$} & \multirow[b]{3}{*}{$\begin{array}{l}\text { Glom. } \\
\text { filt. rate } \\
\text { cc./min. }\end{array}$} & \multicolumn{3}{|c|}{ Urine } \\
\hline & & & \multicolumn{2}{|c|}{ Bicarbonate } & \multirow[b]{2}{*}{$\mathbf{p H}$} \\
\hline & & & $\begin{array}{l}\text { Excreted } \\
\text { mEq./ } \\
\text { min. }\end{array}$ & $\begin{array}{l}\text { Reabsorbed } \\
m E q . / 100 \\
c c . G . F .\end{array}$ & \\
\hline \multicolumn{6}{|c|}{ Lactate infusion } \\
\hline-180 & \multicolumn{5}{|c|}{ Infuse inulin in $5 \% \mathrm{~g} . / \mathrm{W}$ at $2.07 \mathrm{cc} . / \mathrm{min}$. } \\
\hline $\begin{array}{l}30 \\
90\end{array}$ & $\begin{array}{l}27.0 \\
27.0\end{array}$ & $\begin{array}{l}103 \\
106\end{array}$ & $\begin{array}{l}.002 \\
.002\end{array}$ & $\begin{array}{l}2.7 \\
2.7\end{array}$ & $\begin{array}{l}5.6 \\
5.4\end{array}$ \\
\hline 120 & \multirow{2}{*}{\multicolumn{5}{|c|}{$\begin{array}{l}\text { Infuse } \frac{M}{6} \text { lactate } 5.5 \mathrm{cc} . / \mathrm{min} . \\
\text { (Continue inulin infusion) }\end{array}$}} \\
\hline & & & & & \\
\hline $\begin{array}{l}200 \\
250 \\
300\end{array}$ & $\begin{array}{l}29.6 \\
32.0 \\
31.7\end{array}$ & $\begin{array}{l}98 \\
98 \\
95\end{array}$ & $\begin{array}{l}.195 \\
.400 \\
.350\end{array}$ & $\begin{array}{l}2.76 \\
2.79 \\
2.8\end{array}$ & $\overline{7.6}$ \\
\hline \multicolumn{6}{|c|}{ Potassium deprivation six days } \\
\hline-180 & \multicolumn{5}{|c|}{ Infuse inulin $5 \% \mathrm{~g} . / \mathrm{W}$ at $2.46 \mathrm{c} . / \mathrm{min}$. } \\
\hline $\begin{array}{r}60 \\
100\end{array}$ & $\begin{array}{l}31.8 \\
32.0\end{array}$ & $\begin{array}{r}107 \\
96\end{array}$ & $\begin{array}{l}.001 \\
.001\end{array}$ & $\begin{array}{l}3.18 \\
3.2\end{array}$ & $\begin{array}{l}5.7 \\
5.6\end{array}$ \\
\hline
\end{tabular}

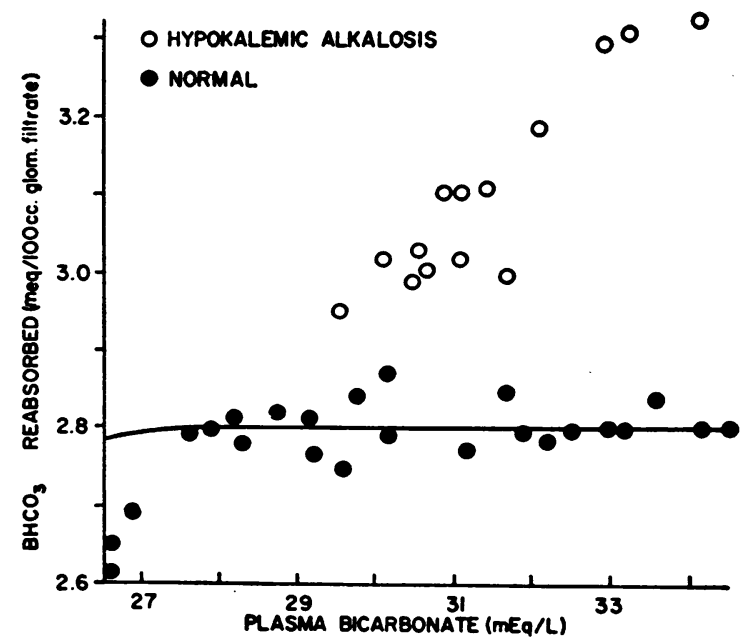

Fig. 1. Reabsorption of Bicarbonate in Normal Patients and in Hypokalemia Patients

The solid circles represent single determinations of bicarbonate reabsorption as calculated prior to and during the infusion of alkali. Four to five determinations of bicarbonate reabsorption were measured on each patient at varying plasma levels of bicarbonate as indicated. The open circles represent the average bicarbonate reabsorption as calculated from three clearance periods and three plasma analyses during the period of hypokalemia. (Bicarbonate reabsorption was measured in four of the patients on two separate occasions during the interval of hypokalemia.)

studied : a) In the control period following the infusion of sodium lactate; and b) following an interval of six days of potassium deprivation after surgery. The infusion of lactate resulted in frank urinary excretion of bicarbonate and an alkaline urine, whereas the renal tubular reabsorption of bicarbonate remained essentially normal. The same patient during the hypokalemia interval, at a time when plasma levels of bicarbonate and $\mathrm{pH}$ showed an elevation comparable to that seen following lactate, showed an increase in bicarbonate reabsorption and the excretion of an acid urine containing sparse amounts of bicarbonate. The data obtained in this patient were similar to those observed in all of the patients studied, and are summarized in Figure 1. This figure illustrates the difference in renal tubular reabsorption of bicarbonate in normal patients given an alkaline load, and in patients exhibiting hypokalemic alkalosis."

- It has been emphasized that potassium influences bicarbonate reabsorption only with intracellular losses of considerable magnitude; no alteration in bicarbonate reabsorption occurs following an acute decrease in extracellular potassium concentration as produced by alkali in- 
TABLE II

\begin{tabular}{|c|c|c|c|c|}
\hline & & & Hypo & alemia \\
\hline & $\begin{array}{c}\mathrm{pCO}_{2} \\
m \boldsymbol{m} . \mathrm{H}_{\mathbf{g}}\end{array}$ & $\begin{array}{l}\text { Glom } \\
\text { filt. rate } \\
\text { cc./min. }\end{array}$ & $\begin{array}{c}\mathrm{pCO} \\
m m \cdot \mathrm{H}_{\mathrm{g}}\end{array}$ & $\begin{array}{l}\text { Gilom } \\
\text { cilt. rate } \\
\text { c./min. }\end{array}$ \\
\hline 1) & $\begin{array}{l}43 \\
43 \\
49 \dagger\end{array}$ & $\begin{array}{l}90 \\
89 \\
89\end{array}$ & $\begin{array}{l}\mathbf{4 4} \\
\mathbf{4 4} \\
\mathbf{4 9} \dagger\end{array}$ & $\begin{array}{l}80 \\
82 \\
81\end{array}$ \\
\hline 2) & $\begin{array}{l}43 \\
43 \\
45\end{array}$ & $\begin{array}{r}97 \\
104 \\
108\end{array}$ & $\begin{array}{l}42 \\
43 \\
40\end{array}$ & $\begin{array}{r}107 \\
96 \\
107\end{array}$ \\
\hline 3) & $\begin{array}{l}45 \\
43 \\
49 \dagger\end{array}$ & $\begin{array}{l}95 \\
96 \\
99\end{array}$ & $\begin{array}{l}45 \\
45 \\
48 \dagger\end{array}$ & $\begin{array}{l}97 \\
96 \\
97\end{array}$ \\
\hline 4) & $\begin{array}{l}40 \\
41 \\
44 \dagger\end{array}$ & $\begin{array}{l}87 \\
90 \\
98\end{array}$ & $\begin{array}{l}43 \\
44 \\
46 \dagger\end{array}$ & $\begin{array}{r}101 \\
97 \\
95\end{array}$ \\
\hline 5) & $\begin{array}{l}45 \\
45 \\
50 \dagger\end{array}$ & $\begin{array}{l}102 \\
103 \\
100\end{array}$ & $\begin{array}{l}44 \\
45 \\
44\end{array}$ & $\begin{array}{l}106 \\
105 \\
101\end{array}$ \\
\hline 6) & $\begin{array}{l}42 \\
42 \\
44\end{array}$ & $\begin{array}{l}75 \\
67 \\
75\end{array}$ & $\begin{array}{l}42 \\
44 \\
45\end{array}$ & $\begin{array}{l}57 \\
52 \\
60\end{array}$ \\
\hline 7) & $\begin{array}{r}43 \\
43 \\
-\end{array}$ & $\begin{array}{l}90 \\
86 \\
-\end{array}$ & $\begin{array}{l}45 \\
44 \\
43\end{array}$ & $\begin{array}{l}89 \\
86 \\
80\end{array}$ \\
\hline 8) & & & $\begin{array}{l}40 \\
41\end{array}$ & $\begin{array}{l}74 \\
76\end{array}$ \\
\hline 9) & & & $\begin{array}{l}42 \\
41 \\
44\end{array}$ & $\begin{array}{l}125 \\
126 \\
136\end{array}$ \\
\hline 10) & $\begin{array}{l}\mathbf{4 4} \\
\mathbf{4 4} \\
\mathbf{4 4}\end{array}$ & $\begin{array}{l}79 \\
85 \\
81\end{array}$ & $\begin{array}{l}45 \\
45 \\
45\end{array}$ & $\begin{array}{l}77 \\
78 \\
65\end{array}$ \\
\hline
\end{tabular}

* The figures for glomerular filtration represent three separate clearance periods. The plasma $\mathrm{pCO}_{2}$ represents values calculated from three separate blood samples analyzed in duplicate.

$\dagger$ Blood drawn after morphine administration.

As shown here, the reabsorption of bicarbonate was increased in the hypokalemic patients, as compared to the normal control values of 2.7 to $2.8 \mathrm{mEq}$. per $100 \mathrm{cc}$. of glomerular filtrate. This

fusion or glucose and insulin (13). Furthermore, it is generally recognized that plasma $\mathrm{K}^{+}$levels per se are a poor reflection of total body stores of potassium as measured by metabolic balances or isotopic dilution studies (21). The potassium depleted patients presented here had sustained intracellular as well as plasma losses of potassium. was found to be true at all levels of plasma bicarbonate shown.

Table II shows the calculated plasma $\mathrm{pCO}_{2}$ and glomerular filtration rates in our patients during the control period and during potassium deprivation. As indicated here, no marked changes in plasma $\mathrm{pCO}_{2}$ occurred in these patients despite a plasma alkalosis and an enhanced bicarbonate reabsorption. From this table it is also apparent that a decrease in glomerular filtration rate could not account for the enhanced bicarbonate reabsorption in all of the patients studied. ${ }^{\circ}$

To clarify the effects of potassium on bicarbonate reabsorption and the relationship between potassium and $\mathrm{pCO}_{2}$, experiments were carried out on six dogs. In these experiments, the effects of potassium on the elevated bicarbonate reabsorption, which has been reported to occur in the presence of an elevated plasma $\mathrm{pCO}_{2}$, was evaluated. A typical experiment is presented in Table III ; as shown here, the elevated bicarbonate reabsorption occurring in respiratory acidosis is decreased by the simultaneous administration of potassium chloride. Furthermore, the decrease in bicarbonate reabsorption following potassium administration occurs with plasma levels of $\mathrm{pCO}_{2}$ which are equivalent to those seen during the period of respiratory acidosis alone. The effects of potassium and respiratory acidosis on bicarbonate reabsorption were consistent in all the dogs studied and are summarized in Figure 2. In this figure, the bicarbonate reabsorption per $1000 \mathrm{cc}$. filtrate is plotted in relation to the plasma $\mathrm{PCO}_{2}$; the crosshatched area summarizes the range of normal bicarbonate reabsorption in dogs, as calculated from previously published data (13). As illustrated by the solid circles, the administration of potassium chloride decreased bicarbonate reabsorption to normal levels irrespective of elevations in plasma $\mathrm{pCO}_{2}$; the open circles confirm the observations of others that elevations of plasma $\mathrm{pCO}_{2}$ per se enhance bicarbonate reabsorption (17-19).

6 We have observed and there has been reported a profound decrease in glomerular filtration rate in hypokalemic alkalosis; this was, however, noted by us only in those patients who were more severely alkalotic than the patients reported here, and has been seen most often by us in situations of hypochloremic alkalosis following excessive losses of gastric contents and extracellular fluid. 
TABLE III

Effects of potassium on the enhanced bicarbonate reabsorption occurring with elevation of plasma $\mathrm{pCO}_{2}$ in dogs

\begin{tabular}{|c|c|c|c|c|c|c|}
\hline \multirow{4}{*}{$\begin{array}{l}\text { Time } \\
\text { mins. }\end{array}$} & & & \multirow{4}{*}{$\underset{m m . H g}{\mathrm{pCO}}$} & \multicolumn{3}{|c|}{ Urine } \\
\hline & \multicolumn{2}{|r|}{ Plasma } & & \multirow{3}{*}{$\begin{array}{l}\text { Glom. } \\
\text { filt. rate } \\
\text { c../min. }\end{array}$} & \multicolumn{2}{|c|}{ Bicarbonate } \\
\hline & Potassium & Bicarbonate & & & & Reabsorbed \\
\hline & \multicolumn{2}{|c|}{$m E q . / L$} & & & $m E Q . / m i n$. & glom. filt. \\
\hline $\mathbf{0}$ & \multicolumn{6}{|c|}{$\begin{array}{c}\text { Prime- }-\mathrm{NaHCO}, 5 \mathrm{gm} . \\
\text { Start infusion; } \mathrm{NaHCO}_{5}-10 \mathrm{gm} . / \mathrm{L} . ; \text { inulin }-10 \mathrm{gm} . / \mathrm{L} . \text { at } 5 \mathrm{cc} . \mathrm{min} .\end{array}$} \\
\hline $\begin{array}{l}70 \\
90\end{array}$ & $\begin{array}{l}2.9 \\
3.0\end{array}$ & $\begin{array}{l}31 \\
31\end{array}$ & $\begin{array}{l}38 \\
39\end{array}$ & $\begin{array}{l}68 \\
70\end{array}$ & $\begin{array}{l}.270 \\
.280\end{array}$ & $\begin{array}{l}2.7 \\
2.7\end{array}$ \\
\hline 105 & \multicolumn{6}{|c|}{ Inspire $10 \% \mathrm{CO}_{2}-90 \% \mathrm{O}_{2}$} \\
\hline $\begin{array}{l}130 \\
150\end{array}$ & $\begin{array}{l}3.2 \\
3.2\end{array}$ & $\begin{array}{l}33 \\
35\end{array}$ & $\begin{array}{l}106 \\
110\end{array}$ & $\begin{array}{l}71 \\
69\end{array}$ & $\begin{array}{l}.140 \\
.114\end{array}$ & $\begin{array}{l}3.1 \\
3.3\end{array}$ \\
\hline 160 & \multicolumn{6}{|c|}{ Start $\mathrm{KCl}-0.4 \mathrm{mEq} . / \mathrm{min}$} \\
\hline $\begin{array}{l}240 \\
300\end{array}$ & $\begin{array}{l}5.6 \\
6.8\end{array}$ & $\begin{array}{l}32 \\
32\end{array}$ & $\begin{array}{l}112 \\
109\end{array}$ & $\begin{array}{l}71 \\
70\end{array}$ & $\begin{array}{l}.362 \\
.400\end{array}$ & $\begin{array}{l}2.7 \\
2.6\end{array}$ \\
\hline
\end{tabular}

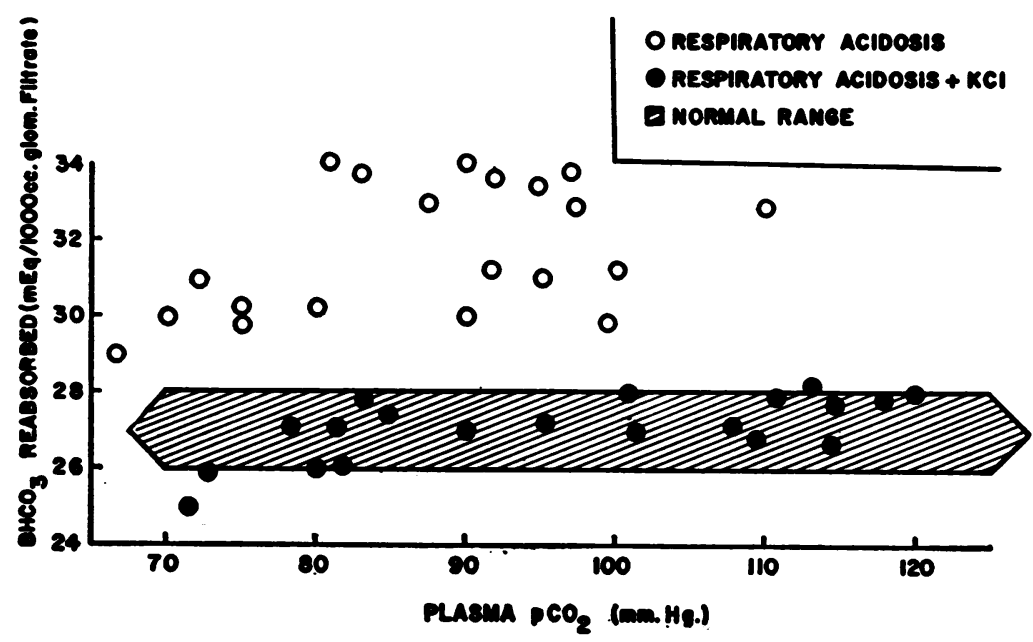

Fig. 2. Bicarbonate Reabsorption in Relation to Plasma $\mathrm{pCO}_{2}$ in Dogs Breathing 10 Per Cent $\mathrm{CO}_{2}$ before (Open Circles) and after the Administration of Potassium Chlortde (Closed Circles)

\section{DISCUSSION}

It is apparent from the data presented that the renal tubular reabsorption of base-bound bicarbonate is increased in the situation of hypokalemia. The enhanced bicarbonate reabsorption in turn would appear to contribute to the plasma alkalosis frequently accompanying potassium depletion. Evidence has been presented that potassium per se affects those renal mechanisms implicated in the stabilization of plasma bicarbonate. Although a decrease in glomerular filtration rate is known to increase bicarbonate reabsorption (22), the changes in glomerular filtration rate reported here could not account for the enhanced bicarbonate reabsorption in all the patients studied. In addition, it has been found that potassium chloride administration will decrease bicarbonate reabsorption in dogs irrespective of alterations in glomerular filtration rate (23).

The notable observations (17-19) that elevations in plasma $\mathrm{pCO}_{2}$ increase the renal absorption of bicarbonate have led to the implication that elevations in plasma $\mathrm{pCO}_{2}$ could enhance the reabsorption of bicarbonate in hypokalemia as well as in respiratory acidosis. The finding in our patients that the plasma $\mathrm{pCO}_{2}$ was little altered does 
not furnish credence to this assumption. The consistent finding of an elevated total $\mathrm{CO}_{2}$ and blood $\mathrm{pH}$ with little change in plasma $\mathrm{PCO}_{2}$ indicates that hypokalemic alkalosis as studied in our patients was uncompensated. Similar elevations of the blood $\mathrm{pH}$ with a normal $\mathrm{pCO}_{2}$ have been observed by us in hypochloremic alkalosis and following alkali infusion in both dog and man. Only with superimposed pulmonary disease, anesthesia or with morphine administration have we consistently observed "respiratory compensations" to occur in metabolic alkalosis (24).

The finding in dogs that potassium decreased the renal tubular reabsorption of bicarbonate to normal levels, irrespective of the level of plasma $\mathrm{pCO}_{2}$, indicates that potassium per se influences bicarbonate reabsorption even with elevations of plasma $\mathrm{pCO}_{2}$. From these experiments and those reported elsewhere, it would appear that potassium and $\mathrm{pCO}_{2}$ affect the renal tubular bicarbonate reabsorption independently and in the opposite direction. This apparent antagonism and the mechanisms whereby $\mathrm{pCO}_{2}$ and potassium affect bicarbonate reabsorption may be reconciled, if consideration is given to implicated alterations of the $\mathrm{pH}$ within the renal tubular cell, as summarized in Figure $3(1,17,25-27)$.

With excessive potassium losses or deprivation, there occurs a depletion of the major intracellular cation. In this situation, a relative intracellular acidosis occurs $(1,2,12,27,28)$, and the meas-

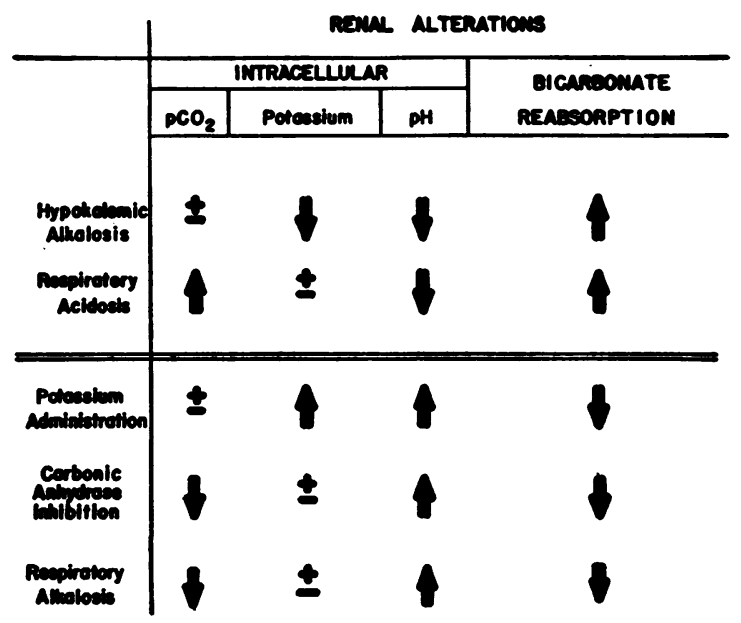

Fig. 3. RELAtionship Betwern Estmated INTRAcellular pH in the Renal Tubules and Measured Bicarbonate Rrabsorption ured bicarbonate reabsorption is increased. The opposite occurs following potassium administration; the increase in intracellular cation concentration which occurs could result in an elevation of the intracellular $\mathrm{pH}$ (16). In this situation, there is a decrease in the measured bicarbonate reabsorption.

Conceivably, a change in extracellular $\mathrm{pCO}_{2}$ results in an equivalent change in intracellular $\mathrm{pCO}_{2}$, since carbon dioxide is believed to permeate all cells, and rapid equilibration is achieved between the extra- and intracellular compartments. Thus, changes in the extracellular $\mathrm{pH}$ resulting from alterations in carbonic acid could effect a similar alteration in the intracellular compartment (29). In respiratory acidosis, elevation of the plasma $\mathrm{pCO}_{2}$ and thus, intracellular carbonic acid, conceivably decreases the intracellular $\mathrm{pH}$. Under these circumstances, the measured bicarbonate reabsorption is increased (17-19). If the simultaneous administration of potassium minimizes the alterations in intracellular $\mathrm{pH}$ by increasing the intracellular cation concentration coincident with the increase of intracellular carbonic acid, the enhanced bicarbonate reabsorption occasioned by the elevated $\mathrm{pCO}_{2}$ should decrease. The experiments summarized in Figure 2 indicate that this does occur, and also provide indirect evidence that alterations in intracellular $\mathrm{pH}$, secondary to alterations in intracellular $\mathrm{pCO}_{2}$ and potassium, influence the renal tubular reabsorption of bicarbonate.

Presumably the decrease in bicarbonate reabsorption following carbonic anhydrase inhibition could also be mediated through changes in intracellular $\mathrm{pH}$ (1). Inhibition of the formation of carbonic acid within the renal tubular cell could result in an increased $\mathrm{pH}$ and thus, a measured decrease in bicarbonate reabsorption. Similarly, the increased bicarbonate excretion, which has been observed following respiratory alkalosis (19, 30,31 ) with a decrease in plasma $\mathrm{pCO}_{2}$, could be accounted for by a decrease in intracellular carbonic acid and elevation of the $\mathrm{pH}$; under these circumstances, the measured renal reabsorption of bicarbonate is decreased.

Although it is impossible by methods currently available to state with certainty that alterations in intracellular potassium do not occur following administration of carbonic anhydrase inhibitors or with alterations in plasma $\mathrm{pCO}_{2}$, evidence pre- 
sented elsewhere indicates that the potassium concentration within the renal tubular cell is unchanged acutely in respiratory acidosis or following the administration of carbonic anhydrase inhibitors (32). From these studies in which measurements of the renal extraction of potassium from arterial blood was compared to the urinary excretion, it was concluded that all potassium removed from the arterial blood during a given interval was excreted in the urine during the same interval. Only with potassium chloride administration was there evidence that the potassium extracted from the arterial blood was not excreted in toto and presumably entered the renal tubular cell. This indirect evidence precludes the implication that alterations in the intracellular potassium per se are responsible for the changes in bicarbonate reabsorption observed in respiratory acidosis or following a carbonic anhydrase inhibitor.

The importance of intracellular $\mathrm{pH}$ alterations in conditioning the reabsorption of bicarbonate has obvious importance in maintaining the bicarbonate concentration of extracellular fluid.

\section{SUMMARY AND CONCLUSIONS}

1. The renal tubular reabsorption of bicarbonate is increased in hypokalemic patients.

2. The increased reabsorption of bicarbonate could not be accounted for by elevations of plasma $\mathrm{pCO}_{2}$.

3. In dogs, the elevated bicarbonate reabsorption, which occurs following elevation of the plasma $\mathrm{pCO}_{2}$, is returned to normal by the administration of potassium chloride without a change in $\mathrm{PCO}_{2}$.

4. Indirect evidence has been presented that a relative change in $\mathrm{pH}$ within the renal tubular cells may be the common denominator by which alterations in potassium and $\mathrm{pCO}_{2}$ affect bicarbonate reabsorption.

\section{REFERENCES}

1. Berliner, R. W., Kennedy, T. J., Jr., and Orloff, J., Relationship between acidification of urine and potassium metabolism: Effect of carbonic anhydrase inhibition on potassium excretion. Am. J. Med., 1951, 11, 274.

2. Black, D. A. K., and Milne, M. D., Experimental potassium depletion in man. Clin. Sc., 1952, 11, 397.
3. Willson, D. M., Power, M. H., and Kepler, E. J., Alkalosis and low plasma potassium in a case of Cushing's Syndrome: A metabolic study. J. Clin. Invest., 1940, 19, 701.

4. Van Slyke, K. K., and Evans, E. I., The paradox of aciduria in the presence of alkalosis caused by hypochloremia. Ann. Surg., 1947, 126, 545.

5. Randall, H. T., Habif, D. V., Lockwood, J. S., and Werner, S. C., Potassium deficiency in surgical patients. Surgery, 1949, 26, 341.

6. Peters, J. P., and Van Slyke, D. D., Quantitative Clinical Chemistry, Vol. I. Baltimore, Williams \& Wilkins, 1931.

7. Gamble, J. L., Fahey, K. R., Appleton, J., and MacLachlan, E., Congenital alkalosis with diarrhea. J. Pediat., 1945, 26, 509.

8. Broch, O. J., Low potassium alkalosis with acid urine in ulcerative colitis. Scandinav. J. Clin. \& Lab. Invest., 1950, 2, 113.

9. Eliel, L. P., Pearson, O. H., and Rawson, R. W., Postoperative potassium deficit and metabolic alkalosis. New England J. Med., 1950, 243, 471.

10. Howard, J. E., and Carey, R. A., The use of potassium in therapy. J. Clin. Endocrinol., 1949, 9, 691.

11. Darrow, D. C., Congenital alkalosis with diarrhea. J. Pediat., 1945, 26, 519.

12. Darrow, D. C., Body-fluid physiology: The role of potassium in clinical disturbances of body water and electrolyte. New England J. Med., 1950, 242, 978, and 1014 (concluded).

13. Roberts, K. E., Magida, M. G., and Pitts, R. F., Relationship between potassium and bicarbonate in blood and urine. Am. J. Physiol., 1953, 172, 47.

14. Winkler, A. W., and Smith, P. K., Renal excretion of potassium salts. Am. J. Physiol., 1942, 138, 94.

15. Berliner, R. W., Kennedy, T. J., Jr., and Hilton, J. G., Renal mechanisms for excretion of potassium. Am. J. Physiol., 1950, 162, 348.

16. Bourdillon, J., Distribution in body fluids and excretion of ingested ammonium chloride, potassium chloride, and sodium chloride. Am. J. Physiol., 1937, 120, 411.

17. Relman, A. S., Etsten, B., and Schwartz, W. B., The regulation of renal bicarbonate reabsorption by plasma carbon dioxide tension. J. Clin. Invest., 1953, 32, 972.

18. Dorman, P. J., Sullivan, W. J., and Pitts, R. F., The renal response to acute respiratory acidosis. $J$. Clin. Invest., 1954, 33, 82.

19. Brazeau, P., and Gilman, A., Effect of plasma $\mathrm{CO}_{2}$ tension on renal tubular reabsorption of bicarbonate. Am. J. Physiol., 1953, 175, 33.

20. Roberts, K. E., Randall, H. T., Farr, H. W., Kidwell, A. P., McNeer, G. P., and Pack, G. T., Cardiovascular and blood volume alterations resulting from intrajejunal administration of hypertonic solutions to gastrectomized patients: The 
relationship of these changes to the dumping syndrome. Ann. Surg., 1954, 140, 631.

21. Moore, F. D., Edelman, I. S., Olney, J. M., James, A. H., Brooks, L., and Wilson, G. M., Body sodium and potassium: III. Interrelated trends in alimentary, renal and cardiovascular disease; lack of correlation between body stores and plasma concentration. Metabolism, 1954, 3, 334.

22. Thompson, D. D., and Barrett, W. J., Effects of variations in glomerular filtration rate on bicarbonate absorption. Federation Proc., 1953, 12, 144.

23. Roberts, K. E., Unpublished observations.

24. Roberts, K. E., Poppell, J. W., Beals, R., Randall, H. T., and Vanamee, P., Failure of respiratory compensations in metabolic alkalosis. In preparation.

25. Berliner, R. W., Renal secretion of potassium and hydrogen ions. Federation Proc., 1952, 11, 695.

26. Orloff, J., Kennedy, T. J., Jr., and Berliner, R. W., The effect of potassium in nephrectomized rats with hypokalemic alkalosis. J. Clin. Invest., 1953, 32, 538.
27. Gardner, L. I., MacLachlan, E. A., and Berman, H., Effect of potassium deficiency on carbon dioxide, cation, and phosphate content of muscle, with a note on the carbon dioxide content of human muscle. J. Gen. Physiol., 1952, 36, 153.

28. Cooke, R. E., Segar, W. E., Cheek, D. B., Coville, F. E., and Darrow, D. C., The extrarenal correction of alkalosis associated with potassium deficiency. J. Clin. Invest., 1952, 31, 798.

29. Wallace, W. M., and Hastings, A. B., The distribution of the bicarbonate ion in mammalian muscle. J. Biol. Chem., 1942, 144, 637.

30. Stanbury, S. W., and Thomson, A. E., The renal response to respiratory alkalosis. Clin. Sc., 1952, 11, 357.

31. Singer, R. B., Clark, J. K., Barker, E. S., and Elkinton, J. R., The effects of acute respiratory alkalosis on electrolyte excretion and renal hemodynamics in man. J. Clin. Invest., 1952, 31, 663.

32. Milch, R. A., Randall, H. T., and Roberts, K. E., Unpublished observations.

\section{SPECIAL NOTICE TO SUBSCRIBERS}

Post Offices will no longer forward the Journal when you move.

Please notify The Journal of Clinical Investigation, Business Office, 622 West 168th Street, New York 32, N. Y. at once when you have a change of address, and do not omit the zone number if there is one. 